\title{
First record of Phaenoglyphis villosa (Hartig, 1841) in Brazil (Hymenoptera: Cynipoidea: Figitidae: Charipinae)
}

\author{
Carlos D. R. Santos ${ }^{1 \pm \pm^{-}(\infty)}$, Marcus V. Sampaio ${ }^{2(}$, Mar Ferrer-Suay ${ }^{3(}$, Luiza R. Redaelli ${ }^{1 \oplus}$, \\ Simone M. Jahnke ${ }^{1 \oplus}$, Douglas Lau ${ }^{4 \oplus}$, Paulo R. V. S. Pereira ${ }^{5 \oplus}$
}

${ }^{1}$ Posgraduate Program in Plant Science, Faculty of Agronomy, Federal Univ of Rio Grande do Sul (UFRGS), Porto Alegre, Rio Grande do Sul, Brazil. ${ }^{2}$ Agricultural Sciences Institute, Federal Univ of Uberlândia (UFU), Uberlândia, Minas Gerais, Brazil. ${ }^{3}$ Museum Valencià d'Història Natural \& Biotaxa, I'Hort de Feliu-Alginet, Apdo. 8460, E-46018, Valencia, España. ${ }^{4}$ Embrapa Trigo, Passo Fundo, Rio Grande do Sul, Brazil. ${ }^{5}$ Embrapa Florestas, Colombo, Paraná, Brazil.

拝=゙Corresponding author: carlosdiegoribeirodossantos@gmail.com

\section{Edited by: Daniell R. R. Fernandes}

Received: March 24, 2020. Accepted: May 19, 2020. Published: June 19, 2020.

\begin{abstract}
Phaenoglyphis villosa (Hartig, 1841) (Hymenoptera: Figitidae: Charipinae) is a secondary endoparasitoid of Aphidiinae (Hymenoptera: Braconidae), a subfamily which are important primary parasitoids of aphids (Hemiptera: Aphididae). It is here registered for the first time in Brazil, collected from primary parasitoids in field-exposed aphids. Phaenoglyphis villosa was recorded during wheat crop season (winter and spring), emerging from Rhopalosiphum padi (Linnaeus, 1758) mummies $(n=35$ \%). It was also recorded from Sitobion avenae (Fabricius, 1775) mummies, in wheat crop season (late winter) $(n=13$ ㅇ) and black oat crop season (late autumn) $(n=1$ ) $)$. We suggest three possible primary braconid parasitoids as hosts to this hyperparasitoid: Aphidius platensis Brèthes, 1913, Aphidius rhopalosiphi de Stefani-Perez, 1902, and Aphidius uzbekistanicus Luzhetzki, 1960.
\end{abstract}

Keywords: hyperparasitoid, cereal aphids, trophic interactions, wheat.

Phaenoglyphis villosa (Hartig, 1841) has been introduced into different continents together with aphids infected with primary parasitoids on their host plants (Pujade-Villar et al. 2011). According to Carver (1992), this species was originated in the Paleartic region. For the Neotropical region, P. villosa was reported in Argentina, Chile and Colombia (Pujade-Villar et al. 2002; Ferrer-Suay et al. 2012a). Phaenoglyphis villosa has been associated with numerous hosts (Pujade-Villar et al. 2011; Ferrer-Suay et al. 2012b), and could be considered a cosmopolitan species, being recorded in all the biogeographic regions (Pujade-Villar et al. 2011; Ferrer-Suay et al. 2012b). This cosmopolitan species has not yet been recorded in Brazil (Gallardo 2020). The species is a secondary solitary endoparasitoid of primary aphid (Hemiptera, Aphididae) parasitoids in the subfamily Aphidiinae (Hymenoptera: Braconidae) and Aphelinus (Hymenoptera: Aphelinidae) (Pujade-Villar et al. 2007).

This is the first record of $P$. villosa from Brazil, and, the possible host associations in wheat plants. There is very little information about the fauna of Charipinae in the Neotropical region (Ferrer-Suay et al. 2012b; 2013), therefore, this record is valuable for adding knowledge about this group, especially on the genus Phaenoglyphis. The Brazilian records of Charipinae subfamily was revised here, with previous occurrence of four species: Alloxysta consobrina (Zetterstedt, 1838) (Betini 1975; 1976; Lazzari 1985; Sousa \& Bueno 1994; Cividanes 2002; Pujade-Villar et al. 2002; Vaz et al. 2004); Alloxysta desantisi Förster (Pujade-Villar et al. 2002); Alloxysta victrix Westwood, 1833 (Peronti et al. 2007); and Apocharips angelicae Pujade-Villar \& Evenhuis, 2002 (Pujade-Villar et al. 2002).

Field bioassay were conducted in a 0.5 ha experimental area (28 $13^{\circ} 43.2^{\prime \prime S} 52^{\circ} 24^{\prime} 04.6^{\prime \prime} \mathrm{W}$ ) of Embrapa Wheat in Passo Fundo (PF), Rio Grande do Sul (RS), Brazil, from August 2018 to July 2019. The climate in the region is humid subtropical, without dry season and with hot summer (Cfa), according to Köppen's classification (Alvares et al. 2014). Meteorological data were obtained from the Embrapa Wheat climatological station $\left(28^{\circ} 13^{\prime} 36.5^{\prime \prime} \mathrm{S} 52^{\circ} 24^{\prime} 12.6^{\prime \prime} \mathrm{W}\right), \mathrm{PF}, \mathrm{RS}$. The study was carried out on a field managed under no-tillage system with the following crop succession: wheat (winter 2018), corn (summer 2018/2019), and black oat (autumn - beginning winter, 2019). Direct recruitment of parasitoids was used. Wheat plants infested with aphids created an artificial environment to attract the hymenopterans. Pots with wheat plants ( 10 plants per pot) at the tillering stage were infested with aviruliferous aphid nymphs and adults (ranged between 50 - 75 aphids per pot). The following aphid (Aphididae) species from mass rearing were used: Rhopalosiphum padi (Linnaeus, 1758), Schizaphis graminum (Rondani, 1852), Metopolophium dirhodum (Walker, 1849), and Sitobion avenae (Fabricius, 1775). Four pots for each aphid species were infested totalizing sixteen pots. After acclimatizing period, infested plant-pots with aphid species were taken to the field. The pots were placed in cages $(39 \times 39 \times 55 \mathrm{~cm})$ lined with polyethylene musket netting $(5 \mathrm{~mm})$ for predator exclusion. Aphids remained exposed for seven days in the field. Posteriorly, they were collected and separated. Each pot was individualized in a rearing cage and kept for seven days in chambers $\left(22 \pm 2{ }^{\circ} \mathrm{C}, 75 \% \pm 10 \mathrm{RH}\right.$; 12 -hour photophase), waiting for mummies formation which were individualized in microtubes $(1,5 \mathrm{~mL})$. Emerged cynipid specimens were identified based on keys to world Charipinae in Ferrer-Suay et al. (2019). Emerged primary parasitoid specimens were identified based on keys of Pennacchio (1989), Kavallieratos et al. (2008), Starý \& Lukáš (2009), Tomanović et al. (2003; 2014; 2018). Scanning electron microscopy was performed with Vega 3-TESCAN Equipment at the Multiuse Center of the University of Passo Fundo, RS, Brazil. Photos of the body lateral view (Fig. 1a), mesopleuron (Fig. 1b), female antenna (Fig. 1c), mesoescutum (Fig. 1d), scutellum and propodeum (Fig. 1e) and pronotum (Fig. 1f) 
were analyzed to confirm the morphological characters of $P$. villosa. Forewing (Fig. 2a) and radial cell (Fig. 2b) photos were obtained using a camera Moticam-1000 attached to a stereoscopic microscope at the Entomology Laboratory, Embrapa Wheat, PF, RS.

In this field assay, P. villosa was recorded during wheat crop season (winter and spring), emerging from $R$. padi $(\mathrm{n}=35$ ㅇ). This species was sampled from 08/19/2018 until 11/01/2018. At this period, the mean air temperature ranged from 16.0 to $18.6^{\circ} \mathrm{C}$. At the same period, the primary parasitoids species emerging from this aphid were Aphidius platensis Brèthes, 1913 and Aphidius rhopalosiphi De Stefani, 1902 (Hymenoptera, Braconidae, Aphidiinae).

Phaenoglyphis villosa was also recorded hyperparasitizing mummies of $S$. avenae, once during wheat crop season (end of winter, $09 / 19 / 2018, n=13$ P), when mean air temperature of week was $16.0^{\circ} \mathrm{C}$. At this moment, the primary parasitoids potential hosts registered on S. avenae were: A. rhopalosiphi and Aphidius uzbekistanicus Luzhetzki, 1960. Another record was during black oat crop season (late autumn,
$06 / 20 / 2019, \mathrm{n}=1$ ㅇ), when the mean air temperature of week was $17.7^{\circ} \mathrm{C}$, and the primary parasitoid hosts sampled in S. avenae were: $A$. platensis and $A$. rhopalosiphi. Phaenoglyphis villosa was not recorded during corn season (summer) and did not emerged from mummies of $S$. graminum and $M$. dirhodum exposed during this bioassay. Based on this data, three possible primary braconid parasitoids could act as hosts to $P$. villosa in Brazil: A. rhopalosiphi, A. platensis and $A$. uzbekistanicus.

Complete description and images of $P$. villosa could be consulted on www.charipinaedatabase.com. Reference specimens of this work were deposited at Museum of Natural Sciences of Secretariat for the Environment and Infrastructure (SEMA), Porto Alegre, RS, Brazil. Voucher specimen numbers: P. villosa (MCN96803), A. rhopalosiphi (MCN96796), A. platensis (MCN96793) and A. uzbekistanicus (MCN96830).
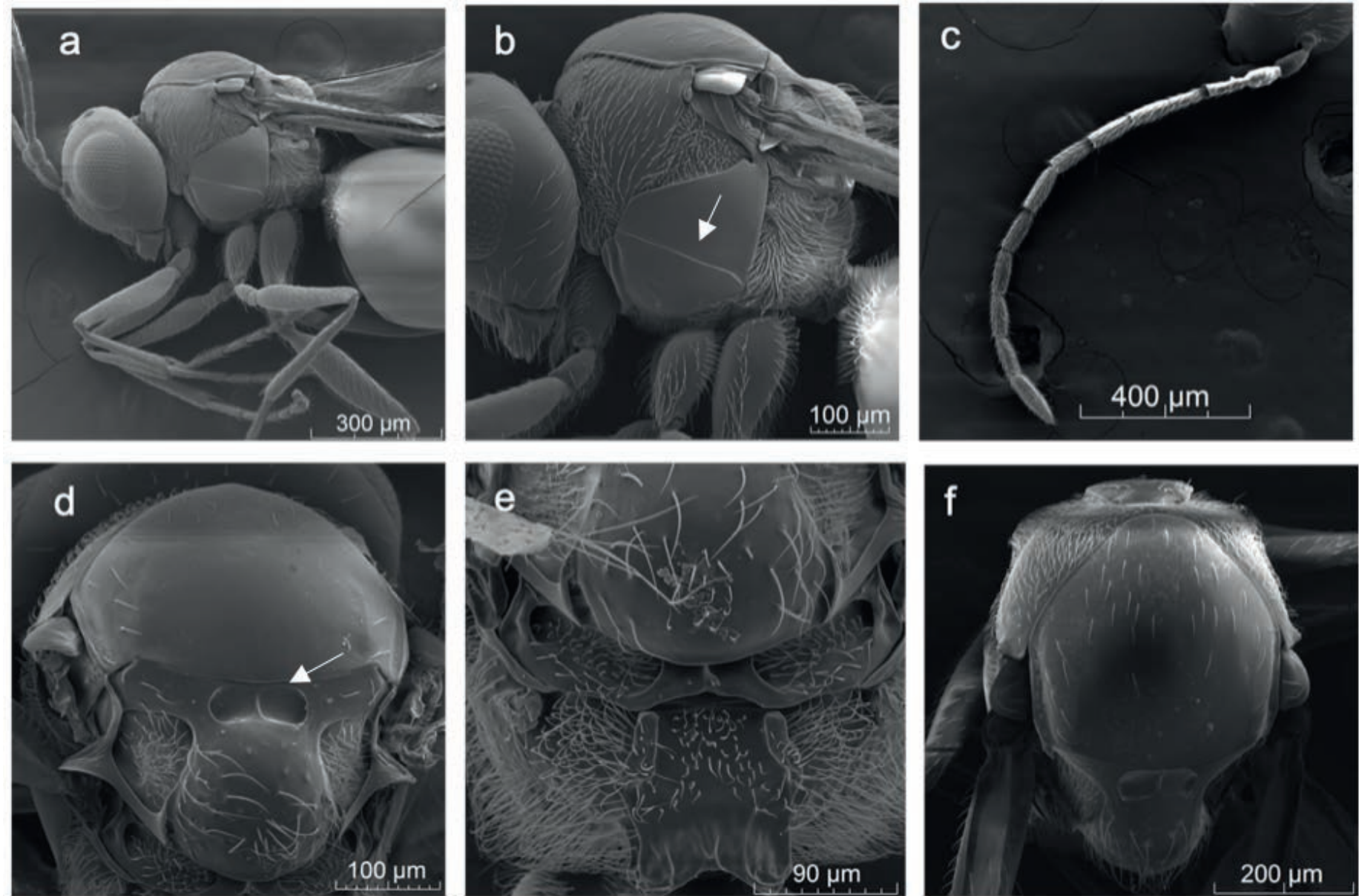

Figure 1. Phaenoglyphis villosa (Hartig, 1841); a body lateral view; b mesopleuron (lateral view, mesopleural furrow, signaled with an arrow); c female antenna; $\mathbf{d}$ mesoscutum (scutellar foveae present, signaled with an arrow); e scutellum and propodeum; $f$ pronotum.
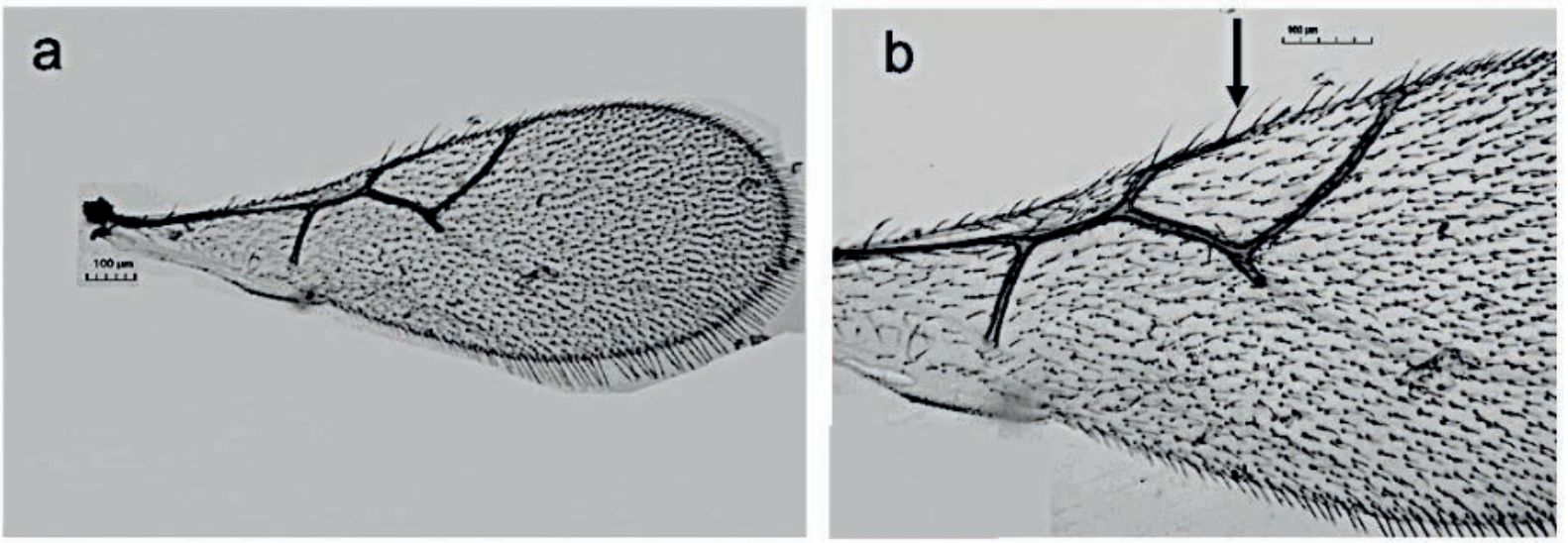

Figure 2. Phaenoglyphis villosa (Hartig, 1841); a forewing; b Radial cell partially open along anterior margin (signaled with an arrow). 


\section{Acknowledgements}

We thank CAPES for a master's degree fellowship (first author), and CNPq research fellowship of the third (CNPq 306626/2019-5) and fourth (CNPq 306435/2015-2) authors. Dr. José Roberto Salvadori from Passo Fundo University permitted us to use the scanning electron microscopy. Dr. Luciano de Azevedo Moura and Dr. Aline Barcellos Prates dos Santos from Natural Sciences Museum - SEMA - RS permitted us to deposit the reference specimens on the entomology collection. This study was supported by the Embrapa project "Integrated platform for monitoring, simulation, and decision making in epidemic management caused by insect-borne viruses" Process: No. 13.16.05.006.00.00.

\section{Authors' contributions}

CDRS, LRR, SMJ, and DL planned, designed experimental work. CDRS executed field bioassay and photos. CDRS, MVS, and MFS made the identification of the species. PRVSP, CDRS, MVS, LRR, SMJ, DL, MFS proposed and wrote the manuscript.

\section{References}

Alvares, C.A.; Stape, J. L.; Sentelhas, P. C.; Gonçalves, J. L. de M.; Sparovek, G. (2014) Köppen's climate classification map for Brazil. Meteorologische Zeitschrift, 22: 711-728. doi: 10.1127/09412948/2013/0507

Betini, A. (1975) Afídeos da macieire (Pyrus malus L.), seus predadores e parasitas. Acta Biológica Paranaense, 4: 33-74.

Betini, A. (1976) Afideos da ameixeira (Prunus domestica L.) e pessegueiro (Prunus persica sto.), seus predadores e parasitas. Acta Biologica Paranaense, 5: 69-90.

Carver, M. (1992) Alloxystinae (Hymenoptera, Cynipoidea, Charipidae) in Australia. Invertebrate Taxonomy, 6: 769-785. doi: 10.1071/ IT9920769

Cividanes, F. J. (2002) Impacto de Inimigos Naturais e de Fatores Meteorológicos Sobre Uma Populaçao de Brevicoryne brassicae (L.) (Hemiptera: Aphididae) em couve. Neotropical Entomology, 31(2): 249-255.

Ferrer-Suay, M; Selfa J; Pujade-Villar J (2012a) Charipinos de Colombia (Hymenoptera: Figitidae), con la descripción de dos nuevas especies. Revista Colombiana de Entomología, 38(2): 320-328.

Ferrer-Suay, M; Paretas-Martínez J, Selfa J; Pujade-Villar J (2012b) Taxonomic and synonymic world catalogue of the Charipinae and notes about this subfamily (Hymenoptera: Cynipoidea: Figitidae). Zootaxa, 3376: 1-92. doi: 10.11646/zootaxa.3376.1.1

Ferrer-Suay, M.; Selfa, J.; Pujade-Villar, J. (2013) Review of the Neotropical Charipinae (Hymenoptera, Cynipoidea, Figitidae). Revista Brasileira de Entomologia, 57(3), 279-299. doi: 10.1590/ S0085-56262013005000020

Ferrer-Suay, M; Selfa J; Pujade-Villar J. (2019) Keys to world Charipinae (Hymenoptera, Cynipoidea, Figitidae). ZooKeys 822: 79-139. doi: 10.3897/zookeys.822.30151

Gallardo, F. (2020) Figitidae in Catálogo Taxonômico da Fauna do Brasil. PNUD. Available at: <http://fauna.jbrj.gov.br/fauna/ faunadobrasil/175860>. Access: 11 April. 2020.

Kavallieratos, N.G.; Tomanović, Ž.; Starý, P.; Mitrovski-Bogdanović, A. (2008) Parasitoids (Hymenoptera: Braconidae: Aphidiinae) attacking aphids feeding on Prunoideae and Maloideae crops in Southeast Europe: aphidiine-aphid-plant associations and key. Zootaxa, 1793, 47-64.

Lazzari, S.N. (1985) Inimigos naturais dos afideos (Homoptera, Aphididae) da cevada (Hordeum sp.) no Paraná. Anais da Sociedade Entomológica do Brazil, 14 (1): 5-15.

Pennacchio, F. (1989) The Italian species of the genus Aphidius Nees (Hymenoptera, Braconidae, Aphidiinae). Bollettino del Laboratorio di Entomologia Agraria'Filippo Silvestri', 46: 75-106.

Peronti, A. L. B. G.; Fraga, F. B.; Rosa, K. C. C.; Teixeira, M. T.; Silva, M. L. (2007) Efeitos da fragmentação florestal e da expansão agrícola sobre a comunidade de insetos fitófagos e himenópteros parasitoides no Parque Nacional da Serra dosÓrgãos e arredores. In: Cronemberger, C.; Viveiros de Castro, E.B. (Org.) Ciência e Conservação na Serra dos Órgãos. Brasília: Ibama.

Pujade-Villar, J.; Fülöp, D., Paretas-Martinez J.; Melika, G. (2011) First record of Phaenoglyphis villosa (Hartig, 1841) from Korea (Hymenoptera: Cynipoidea: Figitidae: Charipinae). Orsis Organismes i Sistemes, 25: 141-146.

Pujade-Villar, J.; Paretas-Martínez, J.; Selfa, J.; Seco-Fernández, M. V.; Fülöp, D.; Melika, G. (2007) Phaenoglyphis villosa (Hartig 1841) (Hymenoptera: Figitidae: Charipinae): a complex of species or a single but very variable species?. In Annales de la Société entomologique de France, 43(2): 169-179.

Pujade-Villar, J; Díaz, N.; Evenhuis, H.H.; Ros-Farré, P. (2002) South American Charipinae: Review and description of two new species (Hymenoptera: Cynipoidea: Figitidae). Annals of the Entomological Society of America, 95(5): 541-546. doi: 10.1603/0013-8746(2002)095[0541:sacrad]2.0.co;2

Sousa, B.M.; Bueno, V.H.P. (1994) Levantamento de predadores e parasitóides adultos associados a Brevicoryne brassicae (Linnaeus, 1758) (Homoptera: Aphididae), em culturas de couve. Boletim do Instituto de Ciencias Biologicas e Geociencias, 46: 23-34.

Starý, P.; Lukáš, J. (2009) Aphid parasitoids and their tritrophic associations in Slovakia (Hymenoptera: Braconidae, Aphidiinae). Bratislava: Folia Hymenopterologica Slovaca, 1: 1-63.

Tomanović, Ž.; Kavallieratos, N.G.; Starý, P.; Athanassiou, C.G.; Žikić, V.; Petrović-Obradović, O.; Sarlis, G.P. (2003) Aphidius Nees (Hymenoptera: Braconidae: Aphidiinae) in Serbia and Montenegro: tritrophic associations and keys. Acta Entomologica Serbica, 8: 1539.

Tomanović, Ž.; Petrović, A.; Mitrović, M.; Kavallieratos, N. G.; Starý, P.; Rakhshani, E.; Rakhshanipour, M.; Popović, A.; Shukshuk A. H.; Ivanović, A. (2014) Molecular and morphological variability within the Aphidius colemani group with redescription of Aphidius platensis Brethes (Hymenoptera: Braconidae: Aphidiinae). Bulletin of Entomological Research, 104(5): 552-565.

Tomanović, Ž.; Mitrović, M.; Petrović, A.; Kavallieratos, N. G.; Žikić, V.; Ivanović, A.; Rakhshani, E.; Starý, P.; Vorburger, C. (2018) Revision of the European Lysiphlebus species (Hymenoptera: Braconidae: Aphidiinae) on the basis of COI and 28SD2 molecular markers and morphology. Arthropod Systematics and Phylogeny, 76(2): 179213.

Vaz, L. A. L.; Tavares, M. T.; Lomônaco. C. (2004) Diversidade e Tamanho de Himenópteros Parasitóides de Brevicoryne brassicae L. e Aphis nerii Boyer de Fonscolombe (Hemiptera: Aphididae). Neotropical Entomology, 30 (2): 225-230. 